\title{
Lithostratigraphical nomenclature of the English Palaeogene succession
}

SIR - Stinton (1975) produced a revised stratigraphical nomenclature for the Eocene portion of the English Palaeogene succession. He rightly claimed (p. 4) that the nineteenth-century nomenclature currently applied to the English Palaeogene succession does not accord with the Geological Society's stratigraphical Code (Harland et al. 1972). Unfortunately, however, Stinton's revised nomenclature, since extended and amplified by Cooper (1976), is also at variance with that code; nor is it compatible with the recommendations in the International Stratigraphic Guide produced under the aegis of the International Subcommission on Stratigraphic Classification (ISSC) (Hedberg, 1976).

In using the terms 'Group' and 'Formation', Stinton attempted a division of the succession into fundamental lithostratigraphical units, correct in principle, but failing in practice to satisfy the requirements of these codes. Both codes state that (1) formations should be the primary lithostratigraphical units; (2) formations should be mappable units, with interformational boundaries placed at positions of lithological change; (3) formations should have a precise definition of lithological character and should be designated at a specific geographical locality, preferably that from which the name of the unit is derived; and (4) the concept of time should not play a part in defining formations and their boundaries.

Amongst the formations proposed by Stinton, only the Bembridge Formation (= Bembridge Limestone of nineteenth-century terminology) complies with these requirements. None of the proposed formations is properly defined lithologically, nor is there any systematic description of the other features required to give them formal validity (see Harland et al. 1972, p. 297). On the contrary, in his Tables 1 and 2, Stinton merely included brief descriptions of different parts of each formation, with no indication of where these parts do or do not occur geographically.

Furthermore, there are indications that Stinton viewed some of his units and unit boundaries in chronostratigraphic terms. In his Table 2, the top of the Bembridge Formation was stated to be the base of the Oligocene, whilst he referred (p. 5) to the correlation of the Earnley and other formations with various Continental stages. It may be too, that the absence of any reference to the Reading Beds in his revised nomenclature suggests that he sees the base of the London Clay as equivalent to the Palaeocene/Eocene boundary.

Instances occur in the revised nomenclature, where boundaries of proposed formations appear to be defined by reference to fossils. For example, the boundary between the proposed Barton and Solent Formations, which coincides with that between the Lower and Middle Headon Beds of the nineteenth-century terminology, is marked by the incoming of a marine fauna and is not primarily lithological in concept. Again, according to Stinton, the base of the Huntingbridge Formation at the type locality is marked by a bed containing a variety of Nummulites prestwichianus.

The use of such criteria is controversial. Although Harland et al. (1972) included palaeontological characters among the wide variety of criteria to be used in the definition of formations, the manner in which they may be used is not precisely stated. However, Harland (1977, p. 231) unequivocally accepted the use of index fossils in lithostratigraphy. This is specifically in opposition to the widely accepted recommendations of the ISSC (Hedberg, 1976), that fossils should only be used if their physical presence characterizes lithology (p. 94).

Curry 'et al. (1977) made one important amendment to Stinton's revised stratigraphic nomenclature. In an account of the lithostratigraphy of the Bracklesham Group at Bracklesham, Stinton's four formations were reclassified as 'divisions', each division being defined 'to include the deposits of a major sedimentary cycle'. The authors stated quite clearly that they were not suggesting a formal stratigraphical status for the divisions. It is our view that many of the 'formations' proposed in Stinton's original paper could well be classified as divisions in this sense.

We consider that a final and practicable lithostratigraphical nomenclature for the English Palaeogene sequence has yet to be achieved. We suggest that the ISSC recommendations (although not mandatory) are to be preferred as a basis for any attempt at a new nomenclature, since they avoid any confusion between litho- and biostratigraphy. It is important that this distinction should be maintained so that the temporal and palaeo-environmental relationships of lithological units may be properly elucidated. We have ourselves informally discussed possible lithostratigraphical nomenclature which would comply with the ISSC usage.

Geol. Mag. 116 (I), 1979, pp. 65-67. Printed in Great Britain. 
However, we feel that the matter could be most rapidly resolved by discussions with other Palaeogene workers, preferably at a meeting convened for this purpose in the near future.

Geology Department

B. DALEY

Portsmouth Polytechnic

Burnaby Road

Portsmouth PO1 3QL

52 Little Paddocks

N. EDWARDS

Ferring

Worthing

Sussex BN $125 \mathrm{NH}$

Museum of Isle of Wight Geology

A. N. INSOLE

Sandown

Isle of Wight

8th June 1978

\section{References}

See page 67 .

SIR - The authors of the preceding letter have kindly provided the writers with a copy in advance of publication to enable them to comment on the criticisms contained in it. The first point which should be made is that the revised nomenclature referred to was born in unusual circumstances. Following editorial pressure, it was produced for inclusion in a Palaeontographical Society Memoir by the present writers after consultation with a number of co-workers. As such, it was necessarily brief, and was designed to include the minimum amount of information to establish the newly proposed units. In addition, of course, it predated the International Stratigraphic Guide (Hedberg, 1976).

In their selection of the names and content of the new units, the present writers tried, so far as practicable, to preserve previous nomenclature. This is clearly desirable from historical, educational and recording viewpoints. At the same time, they wished to emphasize the presence of two marine transgressions (those of the Middle Headon Beds and the Benbridge Oyster Beds), whose importance is not brought out in the previous nomenclature. The new nomenclature follows logically from the above aims, and from the constraints imposed by the availability of geographical names for the newly proposed units, in particular below Formation level.

Whilst the information provided in relation to the new units is less complete than that recommended both in the International Guide and in the Geological Society of London's latest (Harland et al. 1972) guide, it is the present writers' impression that the recommendations in these guides are not mandatory, and may be dealt with by common sense. In particular, when a name is proposed to replace preceding names (now invalid) whose lithology are well known and described elsewhere, it has seemed unnecessary to repeal such descriptions. The analogy with the renaming of a biological taxon is an obvious one. Justification for the view that the recommendations of the Geological Society's guide, at least, are not mandatory may be obtained from a study of the special correlation reports published under the aegis of the Society. Figure 9 of Report No. 8 (Devonian) includes new Formation names which are defined, it seems, only by the information in the Figure. Report No. 5 (Permian) defines Groups without first setting up constituent Formations and, in its designation of new Formations, gives only the sketchiest of lithological descriptions. The most recently issued report (No. 9, Cretaceous) hardly mentions formation names, using them only in relation to the North Sea and the Yorkshire coast.

In paragraph 2 of their letter, Daley et al. list four criteria which, they say, are necessary to satisfy the requirements of the International and English Guides, and add that, of the eight units established by Stinton at Group or Formation level, only one, the Bembridge Formation, satisfies all these criteria. They do not say, however, which, in their opinion, of these criteria are not met by which of Stinton's units. The present writers reply to these somewhat imprecise criticisms as follows.

On criterion 2 (mappability and lithological change), it is observed that the new boundaries coincide in several cases with ones mapped successfully by the Geological Survey for a century or so. The new boundary at the base of the Solent Formation is in general, readily mappable in the basis of lithology and, so far as the formations established within the Bracklesham Group are concerned, it was stressed in Curry et al. (1977, p. 245) that these are believed to be mappable. 
Criterion 3 (definition of lithology and selection of type locality) has already been discussed in part. On the subject of type locality, that for the formations within the Bracklesham Group is given in Curry et al. (1977) as Whitecliff Bay (SZ640860). The type locality of the Barton Formation can, on the basis of the description in Stinton (1975), only be in the cliffs between Mudeford and Milford-on-Sea, Hampshire (SZ200930 to SZ278917), and is here so defined. No type locality is stated for the Solent Formation, and it is here defined as being at Whitecliff Bay (SZ644864). In addition it is here proposed to downgrade the Bembridge Formation of Stinton (1975) to the rank of Member and to include it in the Solent Formation. The succeeding beds (Bembridge Beds, less the Bembridge Limestone, and the Hamstead Beds) are included in a new Hamstead Formation, with type locality at Bouldnor Cliff, Isle of Wight (SZ3991). No type locality is specified in Stinton for his London Clay Group. This unit is most fully developed in the south-eastern part of the London Basin, but the whole is not visible at any one point. A type area is therefore selected here, which includes the cliff sections of Herne Bay and Sheppey in Kent (TQ9274 to TR2168).

It is suggested that some of the proposals of Stinton (1975) are in breach of criterion 4 (that lithostratigraphic boundaries should not be based on a concept of time). This is denied. Table 2 (Stinton, 1975 , p. 7) merely summarizes what is stated on p. 3, which is that the scope of the work (Fish otoliths from the English Eocene) is held to terminate below 'an easily recognizable horizon... lithologically', whose position, in terms of time, 'remains controversial'. The Reading Beds are not discussed by Stinton merely because he considered them to be of Palaeocene age. As it happens, the contact of the Reading Beds with the overlying London Clay provides the most striking and widespread lithological contrast present within the English Palaeogene successions. In this context it seems ludicrous to suggest that the fact that this contact is thought by Stinton to coincide with the base of the Eocene in England could somehow invalidate the concept of the London Clay Group as a lithostratigraphic unit. The objection about the choice of the base of the Middle Headon Beds has been discussed earlier and the statement about the Huntingbridge Formation is erroneous. The type locality of that unit is at Whitecliff Bay, not Huntingbridge (see above), and the sequence at the type locality does not contain the nummulite bed referred to.

In passing, it may be pointed out that it is in fact inconvenient if lithostratigraphic boundaries do not coincide at least with major chronostratigraphic boundaries. Under these circumstances the (lithostratigraphic) boundaries on small-scale maps will be different from those (chronostratigraphic) on large-scale ones. A study of the literature does, happily, suggest that authors of new lithostratigraphic units have, in general, understood this point and have, where practicable, chosen their units accordingly.

No nomenclature is sacrosanct or immutable, and these qualities are not claimed for the one used by Stinton. It is hoped, however, that when modifications are proposed to this, the guiding principles outlined in paragraph 2 of this letter will continue to be adhered to.

51 Craigmoor Avenue

F. C. STINTON

Strouden Park

Bournemouth, Dorset BH8 9LP

Eastbury Grange

Watford Road

Northwood, Middlesex HA6 3PF

19 th July 1978

\section{References}

Cooper, J. 1976. British Tertiary Stratigraphical and rock terms formal and informal, additional to Curry, 1958, Lexique stratigraphique international. Tertiary Research Special Paper 1.

Curry, D., King, A. D., King, C. \& Stinton, F. C. 1977. The Bracklesham Beds (Eocene) of Bracklesham Bay and Selsey, Sussex. Proc. Geol. Ass. 88(4), 243-54.

Harland, W. B. 1977. International Stratigraphic Guide, 1976. Geol. Mag. 114 (3), 229-35.

Harland, W. B. et al. 1972. A concise guide to stratigraphical procedure. Q. Jl geol. Soc. Lond. 128, 295-305.

Hedberg. H. D. 1976. International stratigraphic guide: a guide to stratigraphic classification, terminology and procedure. New York: Wiley.

Stinton, F. C. 1975. Fish Otoliths from the English Eocene, Part 1. Palaeontogr. Soc. [Monogr.]. 